Article

\title{
New Terpenes from the Egyptian Soft Coral Sarcophyton ehrenbergi
}

\section{Ahmed Elkhateeb ${ }^{1}$, Ahmed A. El-Beih ${ }^{2}$, Amira M. Gamal-Eldeen ${ }^{3}$, Montaser A. Alhammady ${ }^{4}$, Shinji Ohta ${ }^{5}$, Paul W. Paré ${ }^{6}$ and Mohamed-Elamir F. Hegazy ${ }^{7, *}$}

1 Phytochemistry and Plant Systematic Department, National Research Centre, El-Tahrir St., Dokki, Giza 12311, Egypt; E-Mail: chem_ahmed@hotmail.com

Department of Chemistry of Natural \& Microbial Products and Center of Excellence Advanced

Sciences, National Research Centre, El-Tahrir Street, Dokki, Giza 12311, Egypt;

E-Mail: aae2eg@yahoo.com

3 Cancer Biology Lab, Center of Excellence for Advanced Sciences \& Biochemistry Department, National Research Center, Dokki, Cairo 12311,Egypt; E-Mail: aeldeen7@yahoo.com

4 National Institute of Oceanography and Fisheries, Red Sea Branch, Hurghada 84511, Egypt;

E-Mail: coralreef_niof1@yahoo.com

5 Graduate School of Biosphere Science, Hiroshima University, 1-7-1 Kagamiyama, Higashi-Hiroshima 739-852, Japan; E-Mail: ohta@hiroshima-u.ac.jp

6 Department of Chemistry \& Biochemistry, Texas Tech University, Lubbock, TX 79409, USA;

E-Mail: paul.pare@ttu.edu

7 Chemistry of Medicinal Plants Department and Center of Excellence Advanced Sciences, National Research Centre, El-Tahrir Street, Dokki, Giza 12311, Egypt

* Author to whom correspondence should be addressed; E-Mail: elamir77@live.com; Tel.: +20-122-007-3557; Fax: +20-233-370-931.

Received: 31 December 2013; in revised form: 11 March 2014 / Accepted: 14 March 2014 / Published: 2 April 2014

\begin{abstract}
Chemical investigations of the Egyptian soft coral Sarcophyton ehrenbergi have led to the isolation of compounds $\mathbf{1}-\mathbf{3}$ as well as the previously reported marine cembranoid diterpene sarcophine (4). Structures were elucidated by comprehensive NMR and HRMS experimentation. Isolated compounds were in vitro assayed for cytotoxic activity against human hepatocarcinoma (HepG2) and breast adenocarcinoma (MCF-7) cell lines.
\end{abstract}


Keywords: Sarcophyton ehrenbergi; soft coral; terpenes; cembranoids; sesquiterpenes; cytotoxic activity

\section{Introduction}

The Red Sea serves as an epicenter for marine bio-diversity, with a high endemic biota. Indeed, of the 180 soft coral species identified world-wide, approximately $40 \%$ are native to the Red Sea [1]. Soft coral (Cnidaria: Anthozoa: Octocorallia) are an important structural component of coral reef communities contributing significantly to coral-reef biomass [2,3]. Soft coral have also been the subject of biological studies since the 19th century with coral belonging to the genus Sarcophyton (Alcyoniidae) well recognized as a rich source of terpenoids [4]. For cembranoid-type diterpenes, a wide range of biological activities have been reported including antitumor, ichthyotoxic, anti-inflammatory, neuroprotective, antibacterial, antiangiogenic, antimetastatic, anti-osteoporotic, and cytotoxic properties [5]. Diterpenes have been isolated previously from Sarcophyton ehrenbergi [6-10]; however, to the best of our knowledge, this is the first chemical investigation of the Red Sea soft coral Sarcophyton ehrenbergi (Figure 1). In the course of our research for bioactive substances from marine sources $[11,12]$, chromatographic separation of an ethyl acetate extract of the alcyonacean soft coral, $S$. ehrenbergi has led to the isolation of three compounds 1-3 as well as the previously reported marine cembranoid diterpene sarcophine (4) (Figure 2). Structures of these isolated metabolites were elucidated by comprehensive NMR and HRMS techniques. Identified compounds were in vitro assayed for cytotoxic activity in two human cancer cell lines.

Figure 1. Soft coral Sarcophyton ehrenbergi.

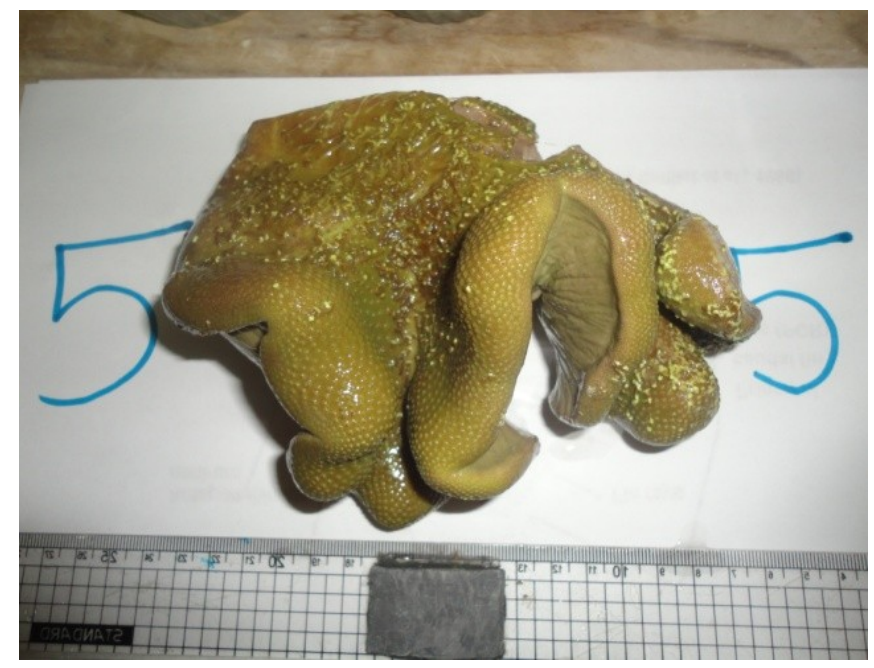


Figure 2. Structures of metabolites 1-4.

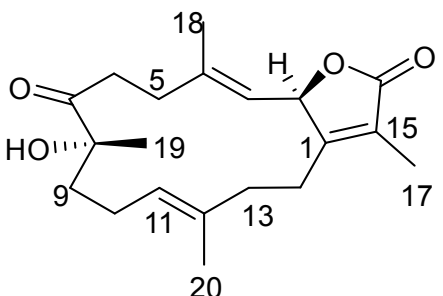

1

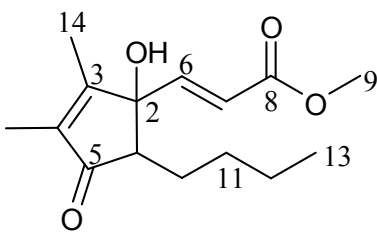

3

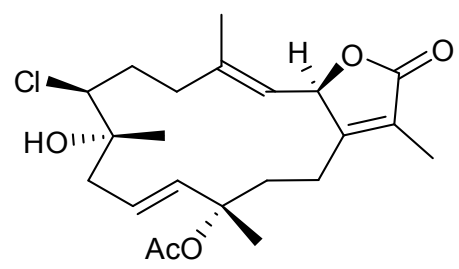

2

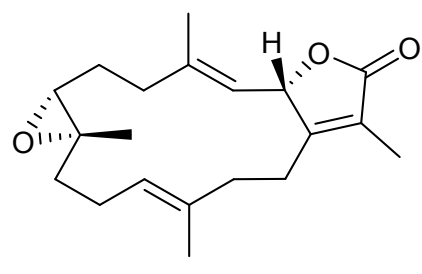

4

\section{Results and Discussion}

The EtOAc extract of freshly collected $S$. ehrenbergi was subjected to normal and reverse phase chromatography to afford the isolated metabolites as reported.

Compound 1 was obtained as a colorless oil. The molecular formula $\mathrm{C}_{20} \mathrm{H}_{28} \mathrm{O}_{4}$, determined by HR-EI-MS ( $m / z$ 332.1935, [M] $]^{+}, \mathrm{C}_{20} \mathrm{H}_{28} \mathrm{O}_{4}$; calcd. 332.1988) points to seven degrees of unsaturation. NMR data were consistent with a sarchophine skeleton previously isolated from other Sarcophyton species [11,12] and reported here (4). Select ${ }^{13} \mathrm{C}$ NMR signals were consistent with an $\alpha, \beta$-unsaturated- $\gamma$-lactone functionality: $\delta 123.1$ (C-15), $\delta 162.9$ (C-1) $\delta 174.9$ (C-16). Carbon NMR chemical shifts (Supplementary Figure S2) established olefinic carbons at $\delta_{\mathrm{C}} 120.2 / 143.9$ (C-3/C-4) and $\delta_{\mathrm{C}} 123.9 / 135.2$ (C-11/C-12), a ketone functionality at $\delta_{\mathrm{C}} 213.5(\mathrm{C}-7)$ and oxygen functionalities at $\delta_{\mathrm{C}} 79.4(\mathrm{C}-2)$ and $\delta_{\mathrm{C}} 78.6(\mathrm{C}-8)$; all signals were consistent with a sarchophine skeleton. The olefin carbons at $\mathrm{C}-3$ and $\mathrm{C}-11$ were assumed to be in the $E$ configuration based on other sarchophine derivatives [11-13]; this orientation was confirmed by NOESY correlations. The ${ }^{1} \mathrm{H},{ }^{1} \mathrm{H}$ COSY spectrum revealed the coupling of four hydrocarbon regions common to sarchophine skeletons: $\delta_{\mathrm{H}} 5.47$ (d, $\left.J=10.3 \mathrm{~Hz}, \mathrm{H}-2\right)$ and 4.96 (br. d, $\left.J=10.3 \mathrm{~Hz}, \mathrm{H}-3\right) ; \delta_{\mathrm{H}} 2.29\left(\mathrm{~m}, \mathrm{H}_{2}-5\right)$ and $2.46\left(\mathrm{~m}, \mathrm{H}_{2}-6\right)$; $\delta_{\mathrm{H}} 1.87 / 1.98\left(\mathrm{~m}, \mathrm{H}_{2}-9\right), 2.04 / 2.18\left(\mathrm{~m}, \mathrm{H}_{2}-10\right)$ and 4.72 (br. t, $\left.J=7.6 \mathrm{~Hz}, \mathrm{H}-11\right)$ and $\delta_{\mathrm{H}} 2.04\left(\mathrm{~m}, \mathrm{H}_{2}-13\right)$ and 2.29/2.46 (m, $\left.\mathrm{H}_{2}-14\right)$. HMBC correlations (Supplementary Figure S4) between $\mathrm{H}-2$ and $\delta_{\mathrm{C}} 162.9$ $(\mathrm{C}-1), \mathrm{H}-3$ and $\delta_{\mathrm{C}} 31.5(\mathrm{C}-5), \mathrm{H}_{2}-5$ and $\delta_{\mathrm{C}} 143.9(\mathrm{C}-4)$ and $\mathrm{H}_{2}-6 / \mathrm{H}_{2}-5$ and $\delta_{\mathrm{C}} 213.5(\mathrm{C}-7)$ established the carbon linkages from $\mathrm{C}-1$ to $\mathrm{C}-7$. Additionally, correlations between $\mathrm{H}_{2}-9$ and $\delta_{\mathrm{C}} 213.5(\mathrm{C}-7) / 78.6$ $(\mathrm{C}-8) / 123.9(\mathrm{C}-11), \mathrm{H}-11$ and $\delta_{\mathrm{C}} 35.9$ (C-13), $\mathrm{H}_{2}-13$ and $\delta_{\mathrm{C}} 135.2(\mathrm{C}-12) / 162.9(\mathrm{C}-1)$ and $\mathrm{H}_{2}-14$ and $\delta_{\mathrm{C}} 162.9(\mathrm{C}-1) / 79.4$ (C-2) completed connectivities of the 14-membered ring. The methyl groups' positions were established by HMBC correlations between C-3, C-4 and C-5 and $\delta_{\mathrm{H}} 1.94\left(\mathrm{H}_{3}-18\right.$, br. s); C-7, C-8 and C-9 and $\delta_{\mathrm{H}} 1.31\left(\mathrm{H}_{3}-19, \mathrm{~s}\right)$; $\mathrm{C}-11, \mathrm{C}-12$ and $\mathrm{C}-13$ and $\delta_{\mathrm{H}} 1.56\left(\mathrm{H}_{3}-20\right.$, br. s); and C-1, $\mathrm{C}-15$ and $\mathrm{C}-16$ and $\delta_{\mathrm{H}} 1.81\left(\mathrm{H}_{3}-17, \mathrm{~s}\right)$. The relative configuration of 1 was determined on the basis of coupling constants and NOESY experiments. The vicinal coupling constant of $10.3 \mathrm{~Hz}$ between $\mathrm{H}-2$ and $\mathrm{H}-3$ suggested a cis configuration between the $\gamma$-lactone proton (H-2) and the olefinic proton (H-3) 
which was confirmed by observed NOESY correlations (Figure 3). Correlations were observed between Me-19 and H-6 $\left(\delta_{\mathrm{H}} 2.91\right)$ as well as between $\mathrm{H}-9\left(\delta_{\mathrm{H}} 1.98\right)$ and $\mathrm{H}-10\left(\delta_{\mathrm{H}} 2.04\right)$; additionally, $\mathrm{H}-2\left(\delta_{\mathrm{H}} 5.47\right)$ showed a correlation with $\mathrm{H}-18\left(\delta_{\mathrm{H}} 1.94\right)$ and $\mathrm{H}-10\left(\delta_{\mathrm{H}} 2.18\right)$ which indicated that Me-19 and an $\mathrm{OH}$ group at C-8 ( $\left.\delta_{\mathrm{C}} 78.6\right)$ were positioned in $\beta$ and $\alpha$ configurations, respectively [11-13].

Figure 3. NOESY correlations for 1-2.

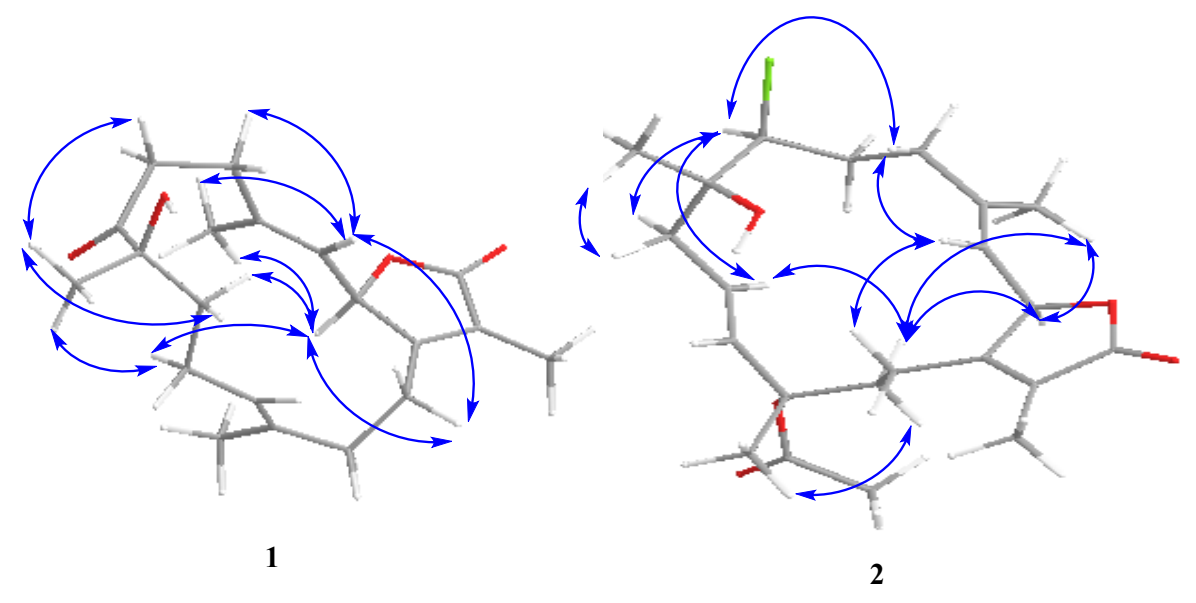

The absolute stereochemistry of $\mathbf{1}$ at $\mathrm{C}-2$ was determined via circular dichroism (CD) analysis (Figure 3). The observed positive Cotton effect $\left([\theta]_{255}+4\right)$ followed by a negative value $\left([\theta]_{225}-24.8\right)$ observed in the CD spectrum (Figure 4 ) for the electronic transitions of the $2(5 H)$-furanone moiety, indicated a left-handed $(M)$ helix configuration for the five-membered $\alpha, \beta$-unsaturated- $\gamma$-lactone ring [14]. CD spectral comparisons between 1 and sarcophine (4) show a shifted spectrum establishing an inverted stereochemistry at C-2 for 1 and $\mathbf{4}$ (Figure 4); with $\mathbf{4}$ having a literature assigned $S$ absolute configuration, the absolute configuration for 1 at $\mathrm{C}-2$ was confirmed to be $R[12,14,15]$. From the above evidence, the structure of $\mathbf{1}$ was confirmed to be 7-keto-8 $\alpha$-hydroxy-deepoxysarcophine (Figure 2).

Figure 4. Circular dichroism spectra of compounds1, 2 and 4.

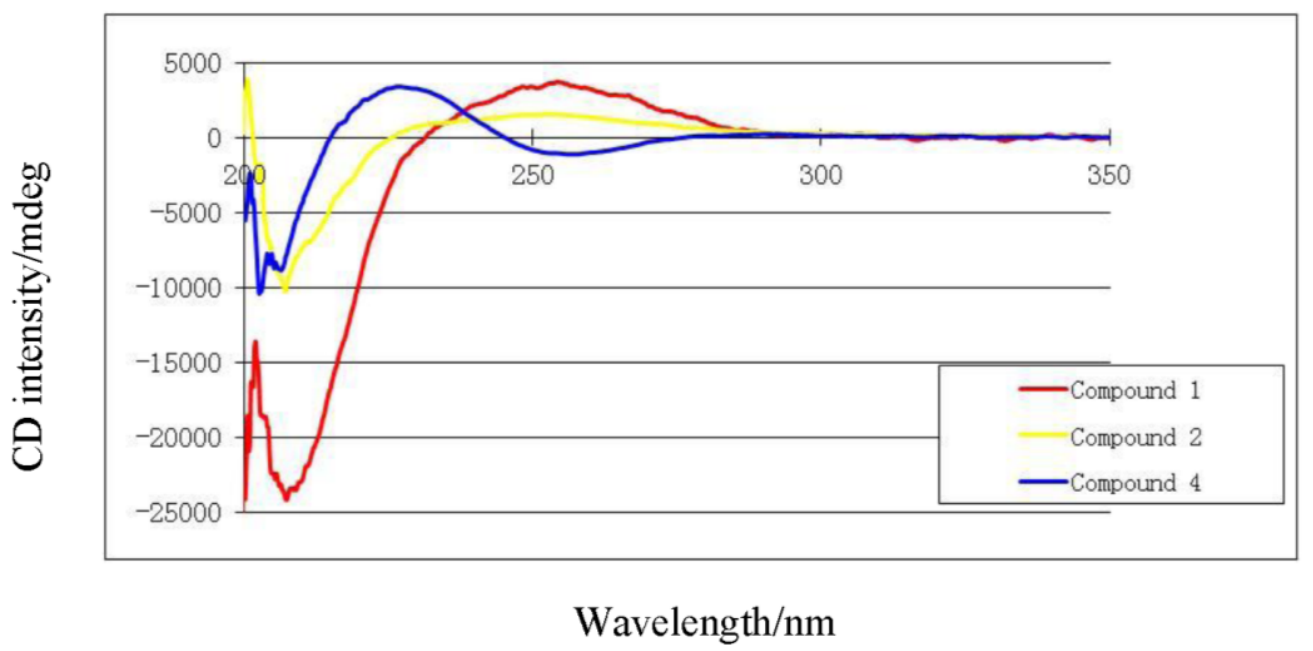

Compound 2 was obtained as a colorless oil. The molecular formula $\mathrm{C}_{22} \mathrm{H}_{32} \mathrm{ClO}_{5}$ was determined by HR-FAB-MS ( $/ z / z$ 411.1943, $[\mathrm{M}+\mathrm{H}]^{+}, \mathrm{C}_{22} \mathrm{H}_{32} \mathrm{ClO}_{5}{ }^{+}$; calcd. 411.1938) and was consistent with seven 
degrees of unsaturation. The NMR spectrum of $\mathbf{2}$ was quite similar to $\mathbf{1}$ except for several noted differences. First, there was a disappearance of the C-7 ketone signal accompanied by the appearance of an up-field signal at $\delta_{\mathrm{C}} 62.9$ (C-7). This C-7 carbon signal was coupled by HMQC (Supplementary Figure S7) with a downfield doublet signal at $\delta_{\mathrm{H}} 3.45(\mathrm{~J}=11.0 \mathrm{~Hz})$ consistent with a chlorine atom at C-7 [13-15]. HMBC correlations (Supplementary Figure S8) between $\delta_{\mathrm{H}} 3.45$ and $\delta_{\mathrm{C}} 36.0(\mathrm{C}-5), 26.3$ (C-6) and 74.8 (C-8) confirmed the proton signal assignment to H-7. Second, there was a downfield shift of C-20 by 9 ppm to $\delta_{\mathrm{C}} 24.4$ accompanied by the appearance of carbonyl and methyl groups at $\delta_{\mathrm{C}}$ 170.0 and 22.2, respectively. These data were consistent with an acetoxy group at $\mathrm{C}-12$ and the displacement of an olefinic bond between $\mathrm{C}-11$ and $\mathrm{C}-12$ (compound 1) to a C-10-C-11 double bond position. This double bond shift was confirmed by COSY correlations starting from $\mathrm{H}_{2}-9$ $\left(\delta_{\mathrm{H}} 2.20 / 2.62, \mathrm{~m}\right)$ correlating with $\delta_{\mathrm{H}} 5.53(\mathrm{H}-10, \mathrm{ddd}, J=15.8,10.3,4.8 \mathrm{~Hz})$ and $\delta_{\mathrm{H}} 5.82(\mathrm{H}-11, \mathrm{~d}$, $J=15.8 \mathrm{~Hz}$ ). HMBC correlations were also observed between $\mathrm{H}_{2}-9$ and $\delta_{\mathrm{C}} 138.2(\mathrm{C}-11)$ and $\mathrm{H}-20$ and $\delta_{\mathrm{C}} 138.2(\mathrm{C}-11), 82.0(\mathrm{C}-12)$ and $41.7(\mathrm{C}-13)$. HMBC correlations were also observed between the acetoxy methyl signal $\left(\delta_{\mathrm{C}} 2.05\right)$ and the carbonyl ester $\left(\delta_{\mathrm{C}} 170\right)$ as shown in Figure 5 (Supplementary Figure S8). The relative configuration of 2 was determined on the basis of coupling constants, and NOESY experiments. The vicinal coupling constant of $10.3 \mathrm{~Hz}$ between H-2 and H-3 suggested a cis configuration between the $\gamma$-lactone proton $(\mathrm{H}-2)$ and the olefinic proton $(\mathrm{H}-3)$ that was confirmed by observed NOESY correlations (Figure 3). The NOE correlations between H-7 and H-10 ( $\delta \mathrm{H}$ 5.53), H-9 $(\delta \mathrm{H} 2.20)$ and Me-18 ( $\left.\delta_{\mathrm{H}} 1.76\right), \mathrm{Me}-18$ and $\mathrm{H}-2$ ( $\delta_{\mathrm{H}}$ 5.42) and Me-19 and H-9 ( $\left.\delta_{\mathrm{H}} 2.62\right)$, indicate a $\beta$ chlorine conformation at C-7 $(\delta \mathrm{C} 62.9)$. In addition, the NOE interactions between $\mathrm{H}-2$ and $\mathrm{H}-14\left(\delta_{\mathrm{H}} 2.20\right)$ and $\mathrm{H}-14\left(\delta_{\mathrm{H}} 2.62\right)$ and $\mathrm{Me}-20\left(\delta_{\mathrm{H}} 1.63\right)$ reveal an $\alpha$ orientation for the acetoxy group at $\mathrm{C}-12$. With nearly equivalent CD spectra observed for $\mathbf{2}$ compared with 1 (Figure 4) assignment of an $(R)$ configuration at $\mathrm{C}-2$ as well as absolute stereochemistry at the other stereo centers was possible $[12,14,15]$. From the above spectral data, 2 was identified as $7 \beta$-chloro- $8 \alpha$-hydroxy-12acetoxy-deepoxysarcophine (Figure 2).

Figure 5. Selected ${ }^{1} \mathrm{H}-{ }^{1} \mathrm{H} \operatorname{COSY}(-)$ and $\operatorname{HMBC}(\rightarrow)$ correlations of $\mathbf{1}-\mathbf{3}$.

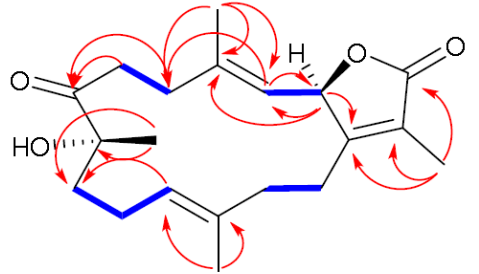

1

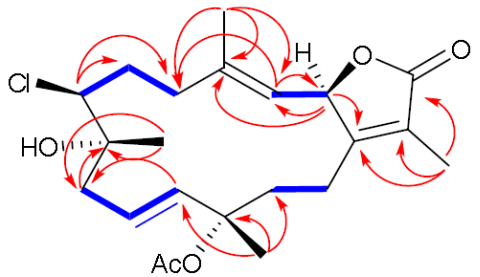

2

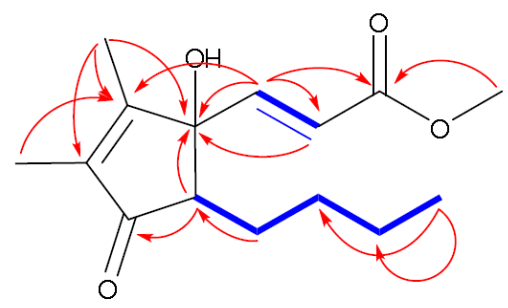


Compound 3 was obtained as a colorless oil. The molecular formula $\mathrm{C}_{15} \mathrm{H}_{22} \mathrm{O}_{4}$ was determined by HR-EI-MS ( $m / z$ 266.1552, [M] $]^{+}, \mathrm{C}_{15} \mathrm{H}_{22} \mathrm{O}_{4}$; calcd. 266.1518) and consistent with five degrees of unsaturation. Starting with a carbonyl carbon based on a chemical shift of $\delta_{\mathrm{C}} 204.7$ (C-5) and HMBC data (Supplementary Figure S12), a cyclopentenone ring structure with two methyl groups was deduced. Informative correlations were observed between $\mathrm{C}-5$ and $\delta_{\mathrm{H}} 1.73\left(\mathrm{H}_{3}-15\right) / 2.42(\mathrm{H}-1)$; H-1 and $\delta_{\mathrm{C}} 82.8(\mathrm{C}-2)$; $\mathrm{C}-2$ and $\delta_{\mathrm{H}} 1.87\left(\mathrm{H}_{3}-14\right) ; \mathrm{H}_{3}-14$ and $\delta_{\mathrm{C}} 165.4(\mathrm{C}-3) / 137.5(\mathrm{C}-4), \mathrm{C}-3$ and $\delta_{\mathrm{H}} 1.73$ $\left(\mathrm{H}_{3}-15\right)$ and $\mathrm{C}-4$ and $\mathrm{H}_{3}-15$. HMBC data established that the pentone ring was linked to olefinic protons via C-2 with correlations observed between C-2 and $\delta_{\mathrm{H}} 6.60(\mathrm{H}-6, \mathrm{~d}, J=15.8 \mathrm{~Hz})$ and C-2 and $\delta_{\mathrm{H}} 6.21(\mathrm{H}-7, \mathrm{~d}, J=15.8 \mathrm{~Hz})$ with the olefin in a $Z$ configuration based on the coupling constant. The methyl ester terminus was linked to an olefinic group through HMBC correlations between H- 6 and $\delta_{\mathrm{C}} 166.4(\mathrm{C}-8)$ as well as between C-8 and H-7. From COSY correlations, a four carbon unbranched saturated hydrocarbon originating from $\mathrm{C}-1$ was identified. The H-1 NMR proton signal correlated with $\delta_{\mathrm{H}} 1.30(\mathrm{H}-10, \mathrm{~m}) / 1.82(\mathrm{H}-10, \mathrm{~m})$; H-10 correlated with $\delta_{\mathrm{H}} 1.32(\mathrm{H}-11, \mathrm{~m}) / 1.45(\mathrm{H}-11, \mathrm{~m}) ; \mathrm{H}-11$ correlated with $\delta_{\mathrm{H}} 1.30(\mathrm{H}-12, \mathrm{~m})$; and $\mathrm{H}-12$ correlated with $\delta_{\mathrm{H}} 0.87(\mathrm{H}-13, \mathrm{t}, J=7.6 \mathrm{~Hz})$. The relative structure of 3 was elucidated by an analysis of coupling constant. The coupling constant of $\mathrm{H}-1(\delta 2.42, \mathrm{dd})$ of 8.9 and $5.5 \mathrm{~Hz}$ indicated that $\mathrm{H}-1$ is on the $\beta$-face. From the above evidence, the structure of 3 was assigned to be (E)-methyl-3-(5-butyl-1-hydroxy-2,3-dimethyl-4-oxocyclopent-2-enyl) acrylate.

Using a 3-[4,5-dimethylthiazole-2-yl]-2,5-diphenyltetrazolium bromide (MTT) spectrophotometric cell-viability assay, the biological activity of the reported coral metabolites to lower human hepatocarcinoma (HepG2) and breast adenocarcinoma (MCF-7) cell-line viability was assayed. The treatment of Hep-G2 cells with metabolites 1-4 (100-12.5 $\mu \mathrm{g} / \mathrm{mL})$ did not exhibit a measureable cytotoxic effect. Metabolites 1-3 exhibited a moderate cytotoxic effect with the MCF-7 cell-line with $\mathrm{IC}_{50}$ values of $192.87,68.57$, and $114.41 \mu \mathrm{mol} / \mathrm{mL}$, respectively.

\section{Experimental Section}

\subsection{General Experimental Procedures}

${ }^{1} \mathrm{H}$ and ${ }^{13} \mathrm{C}$ NMR spectra were recorded in $\mathrm{CDCl}_{3}$ on a JEOL ECA-600 spectrometer $(600 \mathrm{MHz}$ for ${ }^{1} \mathrm{H}$ and $150 \mathrm{MHz}$ for ${ }^{13} \mathrm{C}$, respectively). All chemical shifts $(\delta)$ are given in ppm units with reference to TMS as an internal standard and coupling constants $(J)$ are reported in Hz. FAB-MS was performed on a Finnigan LCQ ion trap mass spectrometer and HR-FAB-MS experiments were performed on Fourier transform ion cyclotron mass spectrometer (Ion Spec, Varian, Walnut Creek, CA, USA). EI-MS experiments were performed using a Thermo ISQ Single Quadrupole system (Thermo Scientific, San Jose, CA, USA). High performance liquid chromatography (HPLC) was performed on an Agilent pump equipped with an Agilent-G1314 variable wavelength UV detector at $254 \mathrm{~nm}$ and a semi-preparative reverse-phase column (Econosphere ${ }^{\mathrm{TM}}$, RP-C18, $5 \mu \mathrm{m}, 250 \times 4.6 \mathrm{~mm}$, Alltech, Deerfield, IL, USA). Optical rotation was determined at $589 \mathrm{~nm}$ (sodium D line) using a Perkin-Elmer-341 MC digital polarimeter (Wellesley, MA, USA); [ $\alpha$ ] D-values are given in units of $10 \mathrm{deg}^{-1} \cdot \mathrm{cm}^{2} \mathrm{~g}^{-1}$. CD was measured with an OLIS, DSM-10 UV/Vis CD (Olis, Bogart, GA, US). Silica gel 60 (230-400 mesh, Merck, Darmstadt, Germany) and Sephadex LH-20 (Sigma, St. Louis, MO, USA) were used for column chromatography. Pre-coated silica gel plates (Merck, Darmstadt, 
Germany, Kieselgel $60 \mathrm{~F}_{254}, 0.25 \mathrm{~mm}$ ) were used for TLC analyses. Spots were visualized by heating after spraying with $10 \% \mathrm{H}_{2} \mathrm{SO}_{4}$.

\subsection{Animal Material}

Soft coral $S$. ehrenbergi was collected from the Egyptian Red Sea off the coast of Hurghada in March 2012. The soft coral was identified by co-author Alhammady with a voucher specimen (03RS27) deposited in the National Institute of Oceanography and Fisheries, Marine Biological Station, Hurghada, Egypt.

Table 1. ${ }^{1} \mathrm{H}$ and ${ }^{13} \mathrm{C}$ NMR spectral data of $\mathbf{1}-\mathbf{3}^{\text {a }}$.

\begin{tabular}{|c|c|c|c|c|c|c|}
\hline \multirow[b]{2}{*}{ Position } & \multicolumn{2}{|c|}{1} & \multicolumn{2}{|l|}{2} & \multicolumn{2}{|l|}{3} \\
\hline & $\delta_{\mathrm{H}}(J$ in $\mathrm{Hz})$ & $\boldsymbol{\delta}_{\mathbf{C}}$ & $\delta_{\mathrm{H}}(J$ in $\mathrm{Hz})$ & $\boldsymbol{\delta}_{\mathrm{C}}$ & $\delta_{\mathrm{H}}(J$ in $\mathrm{Hz})$ & $\boldsymbol{\delta}_{\mathrm{C}}$ \\
\hline 1 & - & $162.9 \mathrm{C}$ & - & $161.9 \mathrm{C}$ & $2.42(\mathrm{dd}, 8.9,5.5)$ & $60.0 \mathrm{CH}$ \\
\hline 2 & $5.47(\mathrm{~d}, 10.3)$ & $79.4 \mathrm{CH}$ & $5.42(\mathrm{~d}, 10.3)$ & $78.3 \mathrm{CH}$ & - & $82.8 \mathrm{C}$ \\
\hline 3 & $\begin{array}{c}4.96(\mathrm{br} \mathrm{d} \\
10.3)\end{array}$ & $120.2 \mathrm{CH}$ & $4.98(\mathrm{~d}, 10.3)$ & $122.2 \mathrm{CH}$ & - & $165.4 \mathrm{C}$ \\
\hline 4 & - & $143.9 \mathrm{C}$ & - & $142.9 \mathrm{C}$ & - & $137.5 \mathrm{C}$ \\
\hline 5 & $\begin{array}{l}2.29(\mathrm{~m}) \\
2.46(\mathrm{~m})\end{array}$ & $31.5 \mathrm{CH}_{2}$ & $\begin{array}{l}2.26(\mathrm{~m}) \\
2.42(\mathrm{~m})\end{array}$ & $36.0 \mathrm{CH}_{2}$ & - & $204.7 \mathrm{C}$ \\
\hline 6 & $\begin{array}{l}2.81(\mathrm{~m}) \\
2.91(\mathrm{~m})\end{array}$ & $34.6 \mathrm{CH}_{2}$ & $\begin{array}{l}1.63(\mathrm{~m}) \\
2.20(\mathrm{~m})\end{array}$ & $26.3 \mathrm{CH}_{2}$ & $6.60(\mathrm{~d}, 15.8)$ & $148.2 \mathrm{CH}$ \\
\hline 7 & - & $213.5 \mathrm{C}$ & $3.45(\mathrm{~d}, 11.0)$ & $62.9 \mathrm{CH}$ & $6.21(\mathrm{~d}, 15.8)$ & $121.5 \mathrm{CH}$ \\
\hline 8 & - & $78.6 \mathrm{C}$ & - & $74.8 \mathrm{C}$ & - & $166.4 \mathrm{C}$ \\
\hline 9 & $\begin{array}{l}1.87(\mathrm{~m}) \\
1.98(\mathrm{~m})\end{array}$ & $39.5 \mathrm{CH}_{2}$ & $\begin{array}{l}2.20(\mathrm{~m}) \\
2.62(\mathrm{~m})\end{array}$ & $43.3 \mathrm{CH}_{2}$ & $3.74(\mathrm{~s})$ & $51.9 \mathrm{CH}_{3}$ \\
\hline 10 & $\begin{array}{l}2.04(\mathrm{~m}) \\
2.18(\mathrm{~m})\end{array}$ & $22.0 \mathrm{CH}_{2}$ & $\begin{array}{c}5.53(\mathrm{ddd}, 15.8,10.3 \\
4.8)\end{array}$ & $123.1 \mathrm{CH}$ & $\begin{array}{l}1.30(\mathrm{~m}) \\
1.82(\mathrm{~m})\end{array}$ & $25.4 \mathrm{CH}_{2}$ \\
\hline 11 & $4.72(\mathrm{brt}, 7.6)$ & $123.9 \mathrm{CH}$ & $5.82(\mathrm{~d}, 15.8)$ & $138.2 \mathrm{CH}$ & $\begin{array}{l}1.32(\mathrm{~m}) \\
1.45(\mathrm{~m})\end{array}$ & $30.1 \mathrm{CH}_{2}$ \\
\hline 12 & - & $135.2 \mathrm{C}$ & - & $82.0 \mathrm{C}$ & $1.30(\mathrm{~m})$ & $22.7 \mathrm{CH}_{2}$ \\
\hline 13 & $2.04(\mathrm{~m})$ & $35.9 \mathrm{CH}_{2}$ & $\begin{array}{l}2.10(\mathrm{~m}) \\
1.38(\mathrm{~m})\end{array}$ & $41.7 \mathrm{CH}_{2}$ & $0.87(\mathrm{t}, 7.6)$ & $13.9 \mathrm{CH}_{3}$ \\
\hline 14 & $\begin{array}{l}2.29(\mathrm{~m}) \\
2.46(\mathrm{~m})\end{array}$ & $25.7 \mathrm{CH}_{2}$ & $\begin{array}{l}2.20(\mathrm{~m}) \\
2.62(\mathrm{~m})\end{array}$ & $21.5 \mathrm{CH}_{2}$ & $1.87(\mathrm{~s})$ & $11.0 \mathrm{CH}_{3}$ \\
\hline 15 & - & $123.1 \mathrm{C}$ & - & $123.5 \mathrm{C}$ & 1.73 (br s) & $8.5 \mathrm{CH}_{3}$ \\
\hline 16 & - & $174.9 \mathrm{C}$ & - & $175.0 \mathrm{C}$ & & \\
\hline 17 & $1.81(\mathrm{~s})$ & $9.0 \mathrm{CH}_{3}$ & $1.84(\mathrm{~s})$ & $8.9 \mathrm{CH}_{3}$ & & \\
\hline 18 & 1.94 (br s) & $18.3 \mathrm{CH}_{3}$ & $1.76(\mathrm{br} \mathrm{s})$ & $15.2 \mathrm{CH}_{3}$ & & \\
\hline 19 & $1.31(\mathrm{~s})$ & $29.0 \mathrm{CH}_{3}$ & $1.32(\mathrm{~s})$ & $23.7 \mathrm{CH}_{3}$ & & \\
\hline 20 & $1.56(\mathrm{br} \mathrm{s})$ & $15.6 \mathrm{CH}_{3}$ & $1.63(\mathrm{~s})$ & $24.4 \mathrm{CH}_{3}$ & & \\
\hline 21 & & & - & $170.0 \mathrm{C}$ & & \\
\hline 22 & & & $2.05(\mathrm{~s})$ & $22.2 \mathrm{CH}_{3}$ & & \\
\hline
\end{tabular}

${ }^{\mathrm{a}}$ Recorded in $\mathrm{CDCl}_{3}$ and obtained at 600 and $150 \mathrm{MHz}$ for ${ }^{1} \mathrm{H}$ and ${ }^{13} \mathrm{C}$ NMR, respectively. 


\subsection{Extraction and Separation}

Frozen soft coral ( $4 \mathrm{~kg}$, total wet weight) was chopped into small pieces and extracted with ethyl acetate at room temperature $(4 \mathrm{~L} \times 5)$. The combined ethyl acetate extracts were concentrated in vacuo to a brown gum. The dried EtOAc-soluble material ( $250 \mathrm{~g}$ ) was subjected to gravity chromatography in a silica gel column $(6 \times 120 \mathrm{~cm})$ using $n$-hexane-EtOAc gradient separated into eight fractions.

Fraction 4 (2.2 g) eluted with $n$-hexane-EtOAc (6:1) was subjected to silica gel column separation to afford $4(100 \mathrm{mg})$. The remaining sub-fraction 4 was collected and re-purified by HPLC using $\mathrm{MeOH} / \mathrm{H}_{2} \mathrm{O}(8: 2 \mathrm{v} / \mathrm{v})$ to afford $3(15 \mathrm{mg})$. Fraction 5 (75.3 $\left.\mathrm{mg}\right)$ was purified by Sephadex LH-20 using hexane- $\mathrm{CHCl}_{3}-\mathrm{MeOH}$ (7:4:0.5) followed by reverse phase $\mathrm{HPLC}$ in $\mathrm{MeOH} / \mathrm{H}_{2} \mathrm{O}(7: 3 \mathrm{v} / \mathrm{v})$ to afford 1 (17 $\mathrm{mg})$, and $2(20 \mathrm{mg})$.

7-Keto-8 $\alpha$-hydroxy-deepoxysarcophine (1): Colorless oil; $[\alpha]_{\mathrm{D}}^{25}=+15.0\left(c 0.03, \mathrm{CHCl}_{3}\right) ;{ }^{1} \mathrm{H}$ NMR and ${ }^{13} \mathrm{C}$ NMR data, see Table 1; HR-EI-MS [M] ${ }^{+} \mathrm{m} / z$ 332.1935 (calc. 332.1988, $\mathrm{C}_{20} \mathrm{H}_{28} \mathrm{O}_{4}$ ).

7 $\beta$-Chloro-8 $\alpha$-hydroxy-12-acetoxy-deepoxysarcophine (2): Colorless oil; $[\alpha]_{\mathrm{D}}^{25}=-20.1$ (c 0.01 , $\mathrm{CHCl}_{3}$ ); ${ }^{1} \mathrm{H}$ NMR and ${ }^{13} \mathrm{C}$ NMR data, see Table 1; HR-FAB-MS $[\mathrm{M}+\mathrm{H}]^{+} \mathrm{m} / z 411.1943$ (calc. 411.1938, $\mathrm{C}_{22} \mathrm{H}_{32} \mathrm{ClO}_{5}$ ).

(E)-Methyl-3-(5-butyl-1-hydroxy-2,3-dimethyl-4-oxocyclopent-2-enyl)acrylate(3): Colorless oil; $[\alpha]_{\mathrm{D}}^{25}=+1.2\left(c 0.01, \mathrm{CHCl}_{3}\right) ;{ }^{1} \mathrm{H}$ NMR and ${ }^{13} \mathrm{C}$ NMR data, see Table 1; HR-EI-MS [M] ${ }^{+} \mathrm{m} / z 266.1552$ (calc. 266.1518 $\mathrm{C}_{15} \mathrm{H}_{22} \mathrm{O}_{4}$ ).

$(+)$-Sarcophine (4): $[\alpha]_{\mathrm{D}}^{25}=+95.0\left(c 0.5, \mathrm{CHCl}_{3}\right) ;$ lit. $[\alpha]_{\mathrm{D}}^{25}=+92\left(c 1.0, \mathrm{CHCl}_{3}\right)[15]$.

\subsection{Cell Culture}

Cell-culture material was purchased from Cambrex BioScience (Copenhagen, Denmark) and chemicals from Sigma-Aldrich (St. Louis, MO, USA), except where noted otherwise. Human hepatocarcinoma and breast adenocarcinoma cell lines, HepG2 and MCF-7 respectively, purchased from the American type culture collection (ATCC, Manassas, VA, USA) were used to evaluate the cytotoxic effect of the isolated metabolites. Cells are routinely cultured in Dulbecco's modified eagle's medium (DMEM) supplemented with 10\% fetal bovine serum (FBS), $2 \mathrm{mM}$ L-glutamine, 100 units $/ \mathrm{mL}$ penicillin $\mathrm{G}$ sodium, 100 units $/ \mathrm{mL}$ streptomycin sulphate and $250 \mathrm{ng} / \mathrm{mL}$ amphotericin B. Cells are maintained at sub-confluency in humidified air at $37{ }^{\circ} \mathrm{C}$ containing $5 \% \mathrm{CO}_{2}$. For sub-culturing, monolayer cells are harvested after trypsin/EDTA treatment. Cells for bioassays were assayed at $75 \%$ confluence. Test compounds were dissolved in dimethyl sulphoxide (DMSO) and diluted to begin with a concentration of $100 \mu \mathrm{g} / \mathrm{mL}$ and serially diluted to a final concentration of $12.5 \mu \mathrm{g} / \mathrm{mL}$. Assays were run in triplicate unless noted otherwise.

\subsection{Anti-Tumor Activity}

Compound cytotoxicity against HepG2 and MCF-7 cell lines was assayed via a 3-[4,5-dimethylthiazole-2-yl]-2,5-diphenyltetrazolium bromide (MTT) spectrophotometric cell-viability assay. The MTT assay is based on the ability of active mitochondrial dehydrogenase enzyme of living cells to cleave the tetrazolium ring of the yellow MTT to form dark-blue insoluble 
formazan crystals that are largely impermeable to cell membranes, resulting in its accumulation within healthy cells. With loss of cell viability, formazan crystals leak into the media. Cell viability is monitored and quantified spectrophotometrically from formazan crystals extracted from the cells [16]. Briefly, cells are diluted in serum-free media to $5.0 \times 10^{4}$ cells/well based on turbidity measurements, plated into flat-bottom 96-well microplates, and incubated for $48 \mathrm{~h}$ with $20 \mu \mathrm{L}$ of test sample. After incubation, media is removed and $40 \mu \mathrm{L}$ MTT $(0.5 \mathrm{mg} \mathrm{MTT} / \mathrm{ml} 0.9 \%$ aqueous $\mathrm{NaCl})$ is added into each well and then incubated for an additional $4 \mathrm{~h}$. MTT crystals are solubilized by adding $180 \mu \mathrm{L}$ of acidified isopropanol to each well and plates are agitated at room temperature, followed by absorbance measurements at $570 \mathrm{~nm}$ using a microplate ELISA reader (BMG LABTECH, Ortenberg, Germany). Triplicate repeats were performed for each concentration and the average was calculated. Data were expressed as the percentage of relative viability compared with the untreated cells and with the vehicle control. Cytotoxicity was reported as a relative viability compared with the untreated control. Percent relative viability was determined based cell viability: (Absorbance of treated cells/absorbance of control cells $) \times 100$. Half maximal inhibitory concentrations $\left(\mathrm{IC}_{50}\right)$ were calculated based on dose-response curves.

\section{Conclusions}

Three new (1-3) and one previously reported (4) terpenes were isolated and chemically characterized from the Red Sea soft coral S.ehrenbergi. Identified compounds 1-3 exhibited in vitro cytotoxic activity against a breast adenocarcinoma cell line (MCF-7) with $\mathrm{IC}_{50}$ values of $192.87,68.57$, and $114.41 \mu \mathrm{m} / \mathrm{mL}$, respectively.

\section{Acknowledgements}

Financial assistance was provided by a grant from the Science and Technology Development Fund (STDF) (1102).

\section{Author Contributions}

Ahmed Elkhateeb, Ahmed A. El-Beih, Mohamed-Elamir F. Hegazy contribute to extraction, isolation, identification and manuscript preparation. Amira M. Gamal-Eldeen contribute to bioactivities test. Montaser A. Alhammady contribute to soft coral collection and identification, Shinji Ohta, Paul W. Paré contribute to structure elucidation, guiding the experiments, analyses and manuscript writing. Mohamed-Elamir F. Hegazy was the project leader organizing and guiding the experiments, structure elucidation, and manuscript writing.

\section{Conflicts of Interest}

The authors declare no conflict of interest. 


\section{References}

1. Edwards, A.J.; Head, S.M. Key Environments-Red Sea; Pergamon Press: Oxford, UK, 1987; p. 440.

2. Tursch, B.; Tursch, A. The soft coral community on a sheltered reef quadrat at Laing Island (Papua New Gunea). Mar. Biol. 1982, 68, 321-332.

3. McFadden, C.S.; Sa'nchez, J.A.; France, S.C. Molecular phylogenetic insights into the evolution of Octocorallia: A review. Int. Comp. Biol. 2010, 50, 389-410.

4. Blunt, J.W.; Copp, B.R.; Hu, W.P.; Munro, M.H.G.; Northcote, P.T.; Prinsep, M.R. Marine natural products. Nat. Prod. Rep. 2008, 25, 35-94.

5. Wang, S.K.; Hsieh, M.K.; Duh, C.Y. Three new Cembranoids from the Taiwanese soft coral Sarcophyton ehrenbergi. Mar. Drugs 2012, 10, 1433-1444.

6. Shaker, K.H.; Mueller, M.; Ghani, M.A.; Dahse, H.M.; Seifert, K. Terpenes from the Soft Corals Litophyton arboreum and Sarcophyton ehrenbergi. Chem. Biodivers. 2010, 7, 2007-2015.

7. Cheng, S.Y.; Wang, S.K.; Chiou, S.F.; Hsu, C.H.; Dai, C.F.; Chiang, M.Y.; Duh, C.Y. Cembranoids from the octocoral Sarcophyton ehrenbergi. J. Nat. Prod. 2010, 73, 197-203.

8. König, G.M.; Wright, A.D. New Cembranoid Diterpenes from the Soft Coral Sarcophyton ehrenbergi. J. Nat. Prod. 1998, 61, 494-496.

9. Bowden, B.F.; Coll, J.C.; Hicks, W.; Kazlauskas, R.; Mitchell, S.J. Studies of Australian soft corals. X. The isolation of epoxyisoneocembrene-A from Sinularia grayi and isoneocembrene-A from Sarcophyton ehrenbergi. Aust. J. Chem. 1978, 31, 2707-2712.

10. Wang, S.K.; Hsieh, M.K.; Duh, C.Y. New diterpenoids from soft coral Sarcophyton ehrenbergi. Mar. Drugs 2013, 11, 4318-4327.

11. Hegazy, M.E.F.; Mohamed, T.A.; Abdel-Latif, F.F.; Alsaid, M.S.; Shahat, A.A.; Paré, P.W. Trochelioid A and B, new cembranoid diterpenes from the Red Sea soft coral Sarcophyton trocheliophorum. Phytochem. Lett. 2013, 6, 383-386.

12. Hegazy, M.E.F.; Gamal Eldeen, A.M.; Shahat, A.A.; Abdel-Latif, F.F.; Mohamed, T.A.; Whittlesey, B.R.; Paré, P.W. Bioactive hydroperoxyl cembranoids from the Red Sea soft coral Sarcophyton glaucum. Mar. Drugs 2012, 10, 209-222.

13. Yin, S.W.; Shi, Y.P.; Li, X.M.; Wang, B.G. A novel hydroperoxyl-substituted cembranolide diterpene from marine soft coral Lobophytum crassum. Chin. Chem. Lett. 2005, 1, 1489-1491.

14. Yao, L.-G.; Liu, H.L.; Guo, Y.W.; Mollo, E. New cembranoids from the Hainan soft coral Sarcophyton glaucum. Helv. Chim. Acta 2009, 92, 1085-1091.

15. Hegazy, M.-E.F.; El-Beih, A.A.; Moustafa, A.Y.; Hamdy, A.A.; Alhammady, M.A.; Selim, R.M.; Abdel-Rehim, M.; Paré, P.W. Cytotoxic cembranoids from the Red Sea soft coral Sarcophyton glaucum. Nat. Prod. Commun. 2011, 6, 1809-1812.

16. Hansen, M.B.; Nielsen, S.E.; Berg, K. Re-examination and further development of a precise and rapid dye method for measuring cell growth/cell kill. J. Immunol. Methods 1989; 119, 203-210.

(C) 2014 by the authors; licensee MDPI, Basel, Switzerland. This article is an open access article distributed under the terms and conditions of the Creative Commons Attribution license (http://creativecommons.org/licenses/by/3.0/). 